Article available at http://www.parasite-journal.org or http://dx.doi.org/10.1051/parasite/2002094293

\title{
Diversification OF CercopithifILARIA SPECIES (Nematoda: Filarioidea) IN JAPANESE WILD RUMINANTS WITH DESCRIPTION OF TWO NEW SPECIES
}

\author{
UNI S.*, BAIN O.**, TAKAOKA H.***, KATSUMI A.****, FUITA H.***** \& SUZUKI Y.******
}

\section{Summary:}

Twelve of the 17 Cervus nippon nippon deer from Kyushu Island, Japan, that we examined were infected with one or two Cercopithifilaria species. C. longa n. sp. adults were in the subcutaneous tissues of limbs and the abdomen, and C. crassa $\mathrm{n}$. sp. adults were in the skin, mainly in the anterior part of the back; the distribution of the dermal microfilariae generally matched that of the adult worms. The two new species were assigned to the group of primitive Cercopithifilaria species tha parasitize ruminants (bovids and cervids), but the new species could readily be distinguished from others morphologically. C. longa was more primitive and resembled C. bulboidea, one of the five species from the serow Capricornis crispus, a Japanese member of the Caprinae, and species from Bovidae in Africa. C. crassa had a thick body and large spicules like

C. rugosicauda from Capreolus capreolus in Europe, the only previously known Cercopithifilaria species from cervids, but it also had one or two hypertrophied pairs of caudal papillae, an unusual character found so far only in Japanese parasites. Among the 12 species known from ruminants, four are African, one is European and more highly evolved, and seven are Japanese, with some being primitive and some more evolved. The great diversity of Cercopithifilaria species in the two wild ruminants that live in Japan seems to have resulted from local speciation, which occurred during the Pleistocene, from a primitive form of the C. longa type derived from Eurasiatic ancestors, which has disappeared or, more probably, not yet been discovered.

KEY WORDS : Filarioidea, Cercopithifilaria, Cervus, sika deer, serow, ruminants, skin, subcutaneous tissue, specific location, phylogeny.

\footnotetext{
* Department of Medical Zoology, Osaka City University Medical School, Osaka 545-8585, Japan.

** Parasitologie comparée et Modèles expérimentaux (associée au Département d'Immunologie, Institut Cochin, INSERM/CNRS/Université René Descartes), Muséum national d'Histoire naturelle et École Pratique des Hautes Études, 75231 Paris Cedex 05, France.

**** Department of Infectious Disease Control, Oita Medical University, Oita 879-5593, Japan.

**** Animal Husbandry Research Center, Yamagata-ken Agricultural Co-op, Yamagata 990-0894, Japan.

***** Ohara Institute, Ohara General Hospital, Fukushima 960-0195, Japan.

****** Laboratory of Veterinary Anatomy, Faculty of Agriculture, Gifu University, Gifu 501-1193, Japan.

Correspondence: S. Uni, Department of Medical Zoology, Osaka City University Medical School, 1-4-3 Asahimachi, Abeno-ku, Osaka 5458585, Japan

Tel.: +81-6-6645-3760 - Fax: +81-6-6645-3762

E-mail: uni@med.osaka-cu.ac.jp
}

Résumé : Diversification de CERCOPITHIFILARIA (NEMATODA: FilarioideA) CHEZ LES RUMINANTS SAUVAGES AU JAPON ET DESCRIPTION DE DEUX NOUVELLES ESPĖCES

Dans l'île de Kyushu Uapon), 12 des 17 Cervus nippon nippon examinés sont parasités par une ou deux espèces de Cercopithifilaria. C. longa n. sp. est situé dans le tissu sous-cutané des pattes et de l'abdomen, C. crassa n. sp. dans la peau, principalement dans la région antérieure du dos; la distribution des microfilaires dermiques suit celle de leurs adultes respectifs. Les deux nouvelles espèces appartiennent au groupe primitif des Cercopithifilaria qui est parasite des ruminants (bovidés et cervidés), mais elles sont bien différentes l'une de l'autre. C. longa est plus primitive et ressemble aux espèces parasites des Bovidae en Afrique ainsi qu'à C. bulboidea, une des cinq espèces parasites du Caprinae japonais, le sérow Capricornis crispus. C. crassa a un corps épais et de grands spicules comme C. rugosicauda, parasite de Capreolus capreolus en Europe et unique espèce connue auparavant chez les cervidés; mais elle a en outre un trait particulier qui se retrouve chez plusieurs parasites du Japon, une ou deux paires de papilles caudales hypertrophiées. Sur les 12 espèces maintenant connues chez les ruminants, quatre sont africaines, une est européenne et plus évolvée, et sept sont japonaises, primitives ou évoluées. La grande diversité des Cercopithifilaria chez les deux ruminants sauvages du Japon semble résulter de spéciations locales, effectuées durant le Pleistocène, à partir d'une forme primitive de type C. longa, issue d'ancêtres eurasiatiques disparus ou, plus vraisemblablement, non encore découverts.

MOTS CLÉS : Filarioidea, Cercopithifilaria, Cervus, sika, sérow, ruminants derme, tissu sous-cutané, distributions spécifiques, phylogénie.

\section{INTRODUCTION}

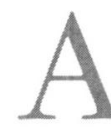

dult worms of the onchocercid genus Cercopithifilaria (Eberhard, 1980) Bain, Baker, Chabaud, 1982 inhabit almost exclusively the subcutaneous tissues and skin of mammals. Their presence is not indicated by any macroscopic lesion and, being small, they can be detected only by methodical examination.

Recent studies (Uni et al., 1998, 2001) have shown five species in the Japanese serow Capricornis crispus, often coexisting in the same animal. The only other wild ruminant in Japan, the sika deer Cervus nippon, was examined also and two new species were discovered, again, often coexisting in the same host.

The new species are particularly interesting because only one member of Cercopithifilaria has been found 
in cervids, a parasite of the roe deer Capreolus capreolus in Europe (Böhm \& Supperer, 1953; Demiaszkiewicz et al., 2001).

\section{MATERIALS AND METHODS}

ika deer, Cervus nippon nippon Temminck, 1838, one of the four subspecies existing in Japan $\checkmark$ (Grubb, 1993), live on Mt. Sobo in Oita Prefecture and elsewhere on Kyushu Island, the large southern island of Japan. Seventeen sika deer were killed between October 1999 and March 2001 in accordance with the policies of the Ministry of the Environment, Japan, concerning their conservation and control. The head with ears, the entire skin of the body together with subcutaneous connective tissues, and the limbs were shipped refrigerated to a laboratory for filarial examination one or two days after the animals were killed.

In examination for microfilariae, skin snips were taken from the face, ears, neck, back, limbs, belly, nipples, and tail of the 17 deer. The skin snips were placed in centrifuge tubes (272; two for each area of the body) with $5 \mathrm{ml}$ of saline and left overnight at room temperature. The skin was removed, the tubes were centrifuged at $600 \times g$ for $10 \mathrm{~min}$, and the supernatant was replaced with $2 \%$ formalin in saline. The tubes were centrifuged again and the precipitant was examined for microfilariae. Their kinds, location in the body, and the number of microfilariae in each tube were recorded on the basis of characteristics of microfilariae taken from females as mentioned below. Blood films were made from each deer and stained with Giemsa's solution, but no microfilariae were found.

For adult filarioids, skin of various parts of the body and limbs was examined under a stereomicroscope. The entire skin and all four limbs of one deer (S15) were examined. During dissection, worms were found either in the loose connective tissue between skin and muscles of carcasses (subcutaneous location), or embedded in the skin, which was 2 to $3 \mathrm{~mm}$ thick, approximately $1 \mathrm{~mm}$ under the black roots of hairs (skin location), in which case it was necessary to cut the skin to recover them.

Adult worms were stored in $2 \%$ formalin in saline and the specimens were cleared in lactophenol for study. As reported before (Uni et al., 2001), caudal papillae of the males were numbered as by Chabaud \& Petter (1961). Microfilariae were taken from the ovejector of living females of each species in saline on glass slides under a stereomicroscope and normal goat serum was dropped on the microfilariae to attach them to the slides. The preparations were dried, fixed with methanol, and stained with Giemsa's solution; the morpho- logic characteristics of each species were used to identify microfilariae in the skin. Drawings of the parasites, histologic sections, and scanning electron micrographs (SEM) of the cuticle were prepared as described elsewhere (Uni, 1983).

Measurements are given in Table I: the body length is expressed in millimeters, the other dimensions are in micrometers; the height of the buccal cavity is the distance from the oral opening to the esophagus; dimensions of the buccal capsule (or ring) are the height $(\mathrm{H})$ and the maximum external diameter (MED); the distance from the apex is given for the nerve ring, the commencement of the testis, and the vulva; length (L) and width (W) are given for the vagina. The structure of the area rugosa was studied and its length measured (anterior and posterior extremities from the tip of tail). The authorities of the new species described below are Uni, Bain \& Takaoka.

\section{RESULTS}

W e present descriptions of the two new species (the first two sections) with each diagnosis, and then their prevalence and distribution in sika deer (the third section).

CERCOPITHIFILARIA LONGA UNI, BAIN

\& TAKAOKA, N. SP. (Table I; Figs 1, 2, and 5A)

Specimens: female holotype (S15-43) and male allotype (S15-71), 302 HS, collection of the Muséum national d'Histoire naturelle (MNHN), Paris. 100 paratypes in the Department of Medical Zoology, Osaka City University Medical School. Other specimens: 262 in the Department of Medical Zoology, Osaka City University Medical School, and 13 specimens in the MNHN (245 HS).

Location in host: adults in subcutaneous connective tissues between muscles and skin of limbs and trunk; microfilariae in skin, mainly of limbs.

Type locality: Mt. Sobo, Ogata-cho, Oita Prefecture, Kyushu, Japan.

The specimens have the general characters of the genus Cercopithifilaria, as described earlier (Bain et al., 1982; Bain et al., 1987; Uni et al., 2001). Round head followed by a slender neck (Fig. 1A). Labial papillae arranged in a rectangle stretched laterally and cephalic papillae in a near-square (Fig. 1B). Amphids with long, wide channel. Buccal capsule small, the external aspect forming two crests (Fig. 1E, arrow). Anterior body swellings in both sexes.

\section{Female}

Four body swellings (Fig. 1H, arrows): the first $3.0 \mathrm{~mm}$ from the anterior end, the second at $3.7 \mathrm{~mm}$, the third 

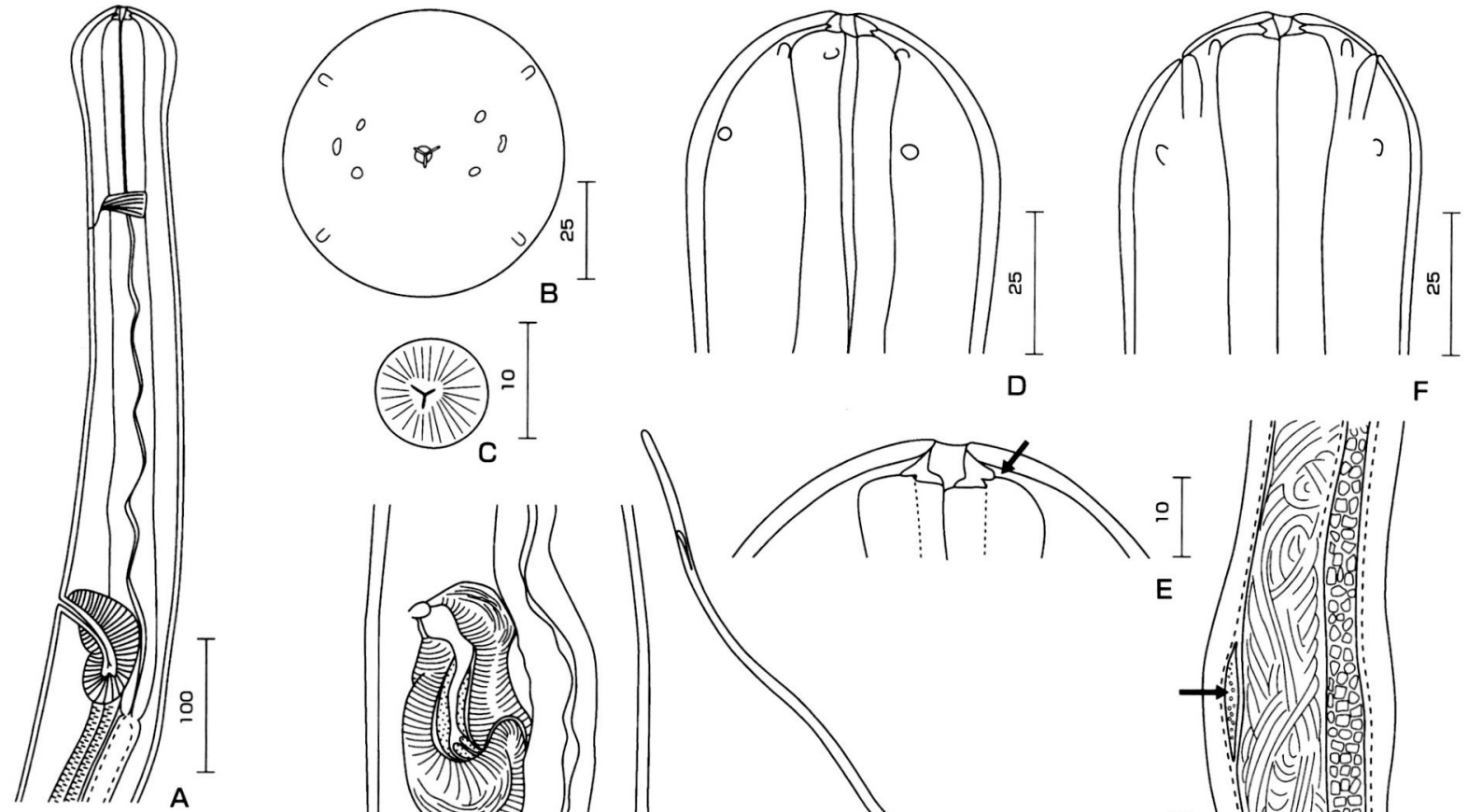

$\mathrm{D}$

$\mathrm{F}$

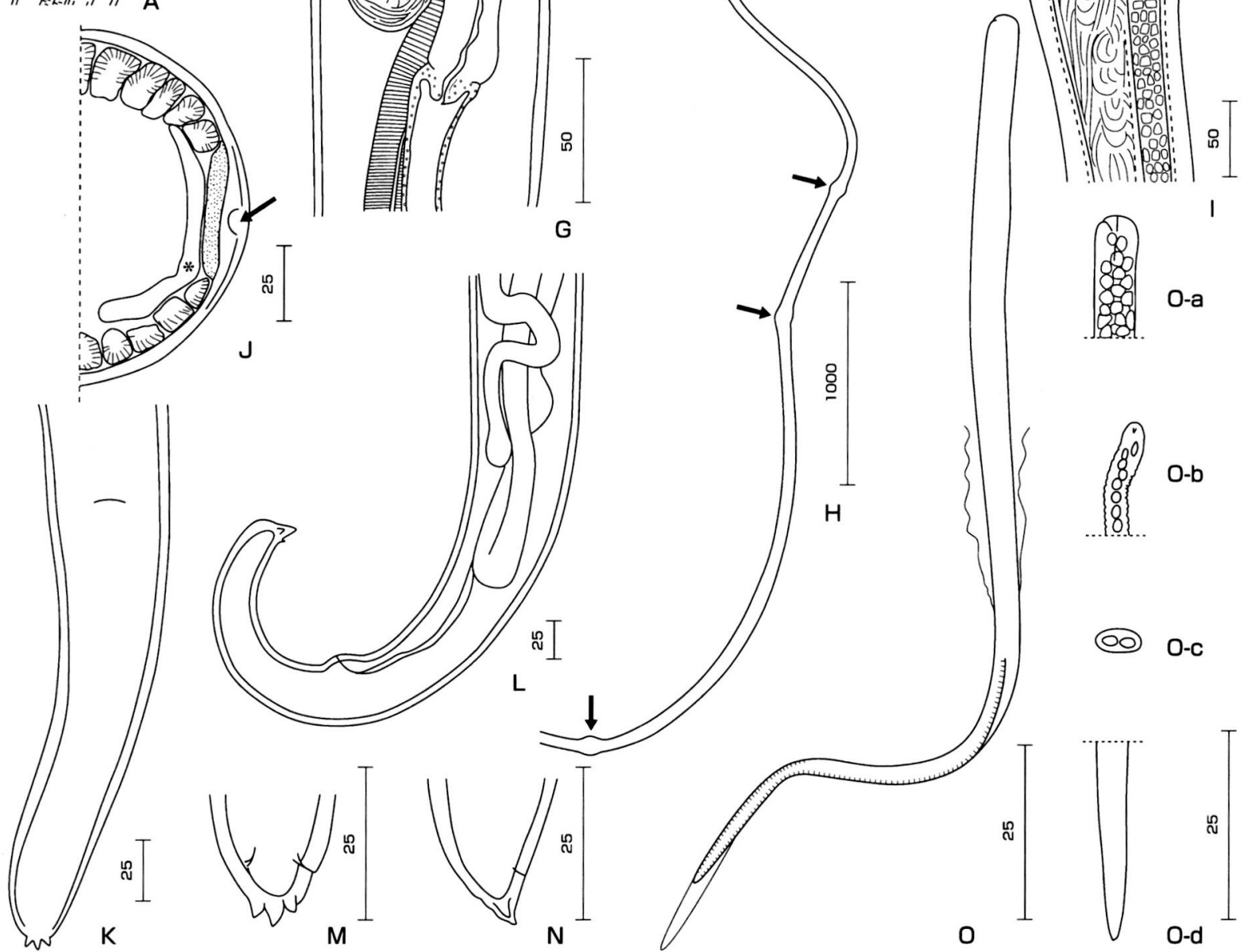

Fig. 1. - Cercopithifilaria longa n. sp. A-N, females. A. Anterior part, lateral view. B. Head, en face view. C. Transverse section of esophagus at base of the buccal capsule. D. Head, lateral view. E. Buccal capsule, lateral view. External crest (arrow). F. Head, median view. G. Vagina, subventral view. H. Anterior part with body swellings (arrows). I. A body swelling with a pseudocoelomocyte (arrow). J. Transverse section of a swelling, with part of a pseudocoelomocyte (*), lateral chord (with small dots), and lateral internal thickening (arrow). K. Tail, ventral view. L. Posterior part, lateral view. M. Caudal extremity, ventral view. N. Caudal extremity, lateral view. O-O-d. Microfilariae. O. Entire body with sheath. O-a. Anterior end, dorsal view. O-b. Anterior end, left lateral view. O-c. Midbody, transverse section. O-d. Caudal part, median view. Bars, micrometers. 


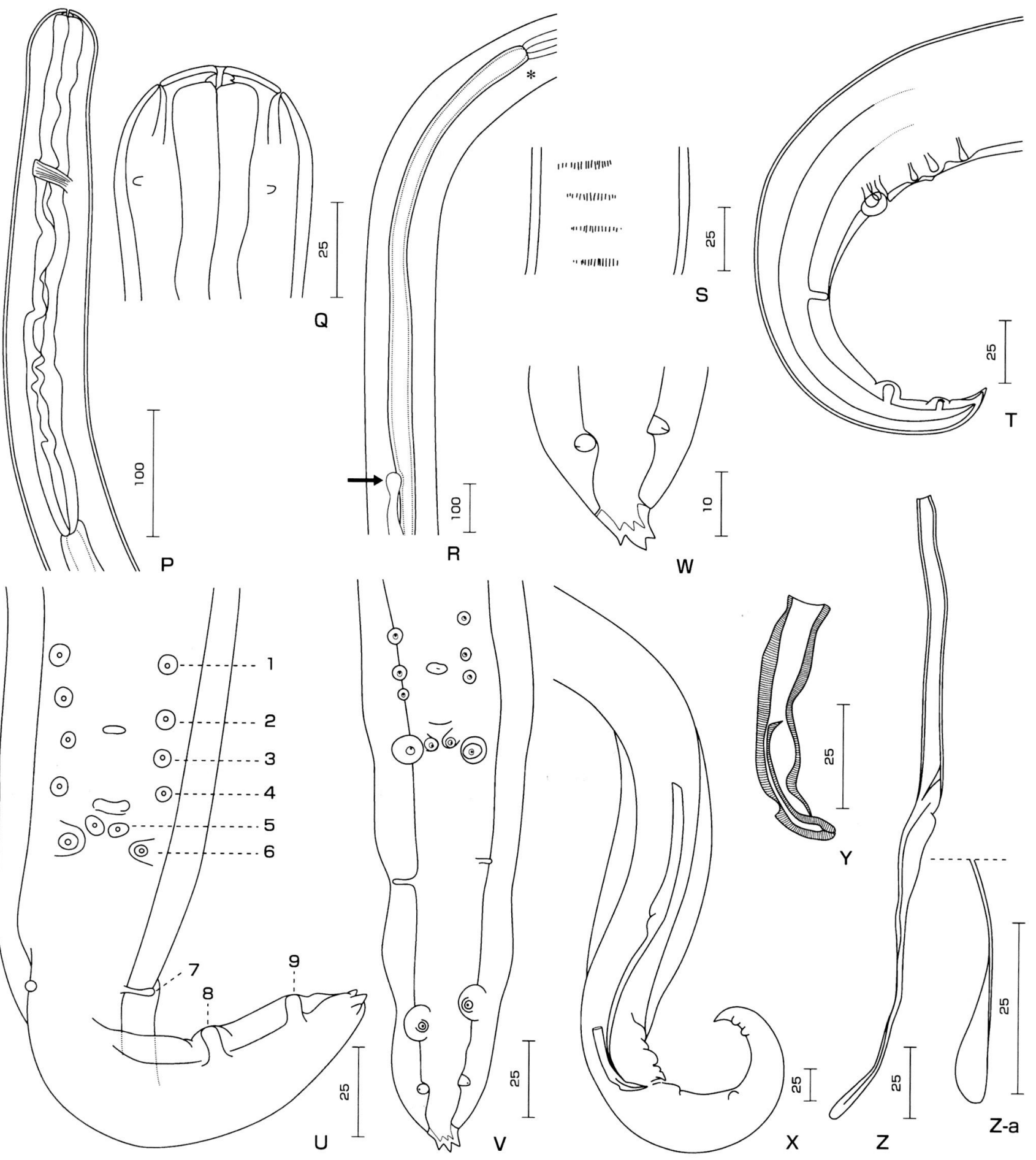

Fig. 2. - Cercopithifilaria longa n. sp. P-Z-a, males. P. Anterior part, lateral view. Q. Head, median view. R. Esophagointestinal junction (*) and position of apex of testis (arrow). S. Area rugosa, ventral view. T. Caudal part, lateral view. U. Tail of a paratype. V. Tail of another paratype, ventral view. W. Caudal extremity, ventral view. X. Posterior part, lateral view. Y. Right spicule, lateral view. Z. Left spicule, lateral view. Z-a. Left spicule, posterior end. Bars, micrometers. 


\begin{tabular}{|c|c|c|}
\hline & C. longa n. sp. & C. $\operatorname{crass} a$ n. sp. \\
\hline Female & $S 15-43(n=5)$ & $\operatorname{S15-77}(n=9)$ \\
\hline Body length & $49(44-53)[49]$ & $39(33-48)[40]$ \\
\hline Body width & $108(108-133)$ [119] & $210(204-280)$ [213] \\
\hline Buccal cavity, $\mathrm{H}^{*}$ & 5 & 8 \\
\hline Buccal ring, $\mathrm{H} / \mathrm{MED}^{*}$ & $3 / 13$ & $5 / 19$ \\
\hline Nerve ring* & $150(146-175)[156]$ & $250(200-275)[227]$ \\
\hline Esophagus & $530(428-590)[492]$ & $740(663-867)$ [749] \\
\hline Vulva* & $650(410-650)$ [542] & $610(600-694)[647]$ \\
\hline Vagina, L/W & $93 / 48$ & $188 / 78$ \\
\hline Ovejector & 2,400 & 700 \\
\hline Tail & $200(153-229)[196]$ & $290(235-350)[273]$ \\
\hline Microfilaria & $\mathrm{n}=10$ & $\mathbf{n}=\mathbf{1 0}$ \\
\hline Body length & $158(150-170)$ [159] & $138(128-140)$ [135] \\
\hline Body width & $5(5-8)[5]$ & $8(5-8)[7]$ \\
\hline Male & $\operatorname{s15-71}(\mathbf{n}=7)$ & S15-B19 $(n=8)$ \\
\hline Body length & $29(21-33)[27]$ & $23(18-25)[22]$ \\
\hline Body width & $78(75-88)[85]$ & $170(163-184)[172]$ \\
\hline Nerve ring* & $145(130-153)[144]$ & $230(193-250)$ [220] \\
\hline Esophagus & $425(425-494)[462]$ & $640(612-750)$ [676] \\
\hline Testicle apex* & 1,570 & 880 \\
\hline Area rugosa, L & 800 & 1,600 \\
\hline Right spicule, L & $60(52-75)[65]$ & $80(76-104)[92]$ \\
\hline Left spicule, L & $228(205-250)[228]$ & $420(415-440)[425]$ \\
\hline Tail & $145(140-168)$ [154] & $165(145-195)$ [165] \\
\hline
\end{tabular}

Holotype and allotype are presented first, followed by ranges and then means. n, number of parasites examined.

*See text.

Table I. - Measurements of adults and microfilariae of species of Cercopithifilaria found in sika deer.

at $7.0 \mathrm{~mm}$, and the fourth at $19.6 \mathrm{~mm}$ in the holotype specimen; a pseudocoelomocyte was present in each swelling (Fig. 1I-J). Cuticular striations perpendicular to the long axis of the body in the lateral field visible by SEM, $0.5 \mu \mathrm{m}$ apart (Fig. 5A). Body cuticle thickened internally laterally (Fig. 1J, arrow).

Vulva near esophagointestinal junction. Vagina slightly longer than wide (Fig. 1G). Ovejector long, without any special structures. Tail bent ventrally, the curve beginning anterior to the anus (Fig. 1L). Two lateroventral lappets and one longer dorsal lappet; no dorsal or ventral crests (Fig. 1M). Phasmids lateral, anterior to the lateroventral lappets.

Microfilaria: cephalic space 5-6 (6) $\mu \mathrm{m}$, nerve ring 3843 (41) $\mu \mathrm{m}$ from anterior end: $26 \%$ of the body length, and excretory pore 48-60 (50) $\mu \mathrm{m}$ from anterior end: $31 \%$ of the body length. Body flattened dorsoventrally (Fig. 1O-a-d), attenuated behind the beginning of the posterior third. Posterior part without nuclei 3-8 (5) $\mu \mathrm{m}$, and narrow but blunt tail end (Fig. 1O-d). Sheath ragged; rarely present on uterine microfilariae, absent from skin microfilariae.

\section{Male}

Body with four swellings at 1.8, 3.3, 5.5, and $9.8 \mathrm{~mm}$ from anterior end of the allotype. Apex of testis far behind the esophagointestinal junction (Fig. 2R). Area rugosa (Fig. 2S): 81 raised transverse bands, $5 \mu \mathrm{m}$ high and $8-10 \mu \mathrm{m}$ apart, extending from 1.3 to $0.5 \mathrm{~mm}$ from the tip of the tail.

Caudal papillae (Fig. 2U-V): four precloacal pairs of papillae, sometimes reduced to three pairs, always somewhat aligned, with lines parallel, and fairly uniformly spaced; one precloacal unpaired papilla at the level of pair 3; pairs 5 and 6 almost on the same transverse line, pair 7 at the midlength of the tail, pairs 8 and 9 far from each other; pairs 6 and 8 larger than the others (Fig. 2V). Tail extremity: a very short, thick cylinder bearing two short lateroventral lappets and a dorsal longer one (Fig. 2W). Spicules (Fig. 2Y-Z-a): the right with long terminal cap and subterminal dorsal heel; the left with handle and lamina of similar length, and the posterior part of the lamina with slightly striated alae.

\section{Diagnosis}

C. longa has a combination of characters that show it to be closely related to the group parasitic in ruminants (bovids and cervids) as defined by Uni et al. (2001): the eight head papillae are present, all caudal papillae are usually present, except for pair 10 , and all are symmetrically arranged on the head and tail.

In C. longa male worms, pair 8 of the caudal papillae was midway between pairs 7 and 9 and thus at some distance from pair 9. This character suggested a relationship between this species and parasites of Bovidae in Africa - C. ruandae Fain \& Hérin, 1955 and C. dermicola Fain, 1977 from cattle, C. faini Chabaud, Landau \& Petit, 1978 from a Cephalophus nigrifrons, of which the male was described for all three - as well as C. bulboidea Uni \& Bain, 2001, one of the five species parasitic in a Japanese bovid, the serow Capricornis crispus. However, all of the species found in the serows have the cylinder of the male caudal extremity better delimited than in C. longa.

Each of these species differs also from C. longa in several other characters:

- C. dermicola has no body swellings, and the spicules are longer $(87 \mu \mathrm{m}$ for the right spicule and $307 \mu \mathrm{m}$ for the left spicule), as are the microfilariae (205$220 \mu \mathrm{m}$ long; 8-9 $\mu \mathrm{m}$ wide) (Fain, 1977).

- C. faini, which seems also to be devoid of body swellings, and which has head papillae and amphids more posterior, the esophagus longer, a postesophageal vulva, the caudal extremity of the female more complex and, in the male, the area rugosa longer $(1,350 \mu \mathrm{m}$, compared with $800 \mu \mathrm{m}$ in Table I), pair 6 of the papillae clearly posterior to pair 5 , and the papillae of pair 7 larger (Chabaud et al., 1978).

- C. ruandae has a shorter body $(28.5-35 \mathrm{~mm}$ in the female, $12.5-18 \mathrm{~mm}$ in the male), with a more attenuated tail in both sexes, a longer esophagus (about $700 \mu \mathrm{m}$ in both sexes), a postesophageal vulva, no body swellings in the male, and longer microfilariae 
(170-195 $\mu \mathrm{m}$ ) with a persistent sheath (Fain \& Hérin, 1955).

- C. bulboidea has longer microfilariae (190-208 $\mu \mathrm{m}$ ) with a different shape (attenuated in the caudal region and not at the beginning of the posterior third of the body), more elongated caudal lappets in both sexes, fewer precloacal papillae (pair 1 or pairs 1 and 2 absent), and the terminal cap of the right spicule less elongated (Uni et al., 2001). This species is morphologically most similar to $C$. longa. Both species are found subcutaneously and they have similar body cuticle (striae perpendicular to the long axis of the body and interrupted on the lateral line), but C. longa seems the most primitive, with a complete set of precloacal papillae and a short terminal cylinder.

A fourth and last African species, known by the female worm only, C. cephalophi Bain, Baker \& Chabaud, 1982 from a Cephalophus dorsalis, also must be discussed because it probably is closely related to the above-mentioned species. It is distinguished from the present material by a shorter body $(29 \mathrm{~mm})$, a longer esophagus $(1,230 \mu \mathrm{m})$, and longer microfilariae (218$232 \mu \mathrm{m}$ ) (Bain et al., 1982).

CERCOPITHIFILARIA CRASSA UNI, BAIN

\& TAKaOKA N. SP. (Table I; Figs 3, 4 and 5B)

Specimens: female holotype (S15-77) and male allotype (S15-B19), 303 HS, MNHN, Paris. 116 paratypes in the Department of Medical Zoology, Osaka City University Medical School. Other specimens; 129 in the Department of Medical Zoology, Osaka City University Medical School and 11 in MNHN (247 HS).

Location in host: adults in skin (dermis, the parasites embedded in skin under the roots of hairs) of anterior back; microfilariae in skin mainly of back.

Type locality: Mt. Sobo, Ogata-cho, Oita Prefecture, Kyushu, Japan.

Conical head without neck. Labial and cephalic papillae in two laterally elongated rectangles, the second less elongated (Fig. 3B). Base of buccal capsule and apex of esophagus with dorsoventrally flattened lumen (Fig. 3C-a-c). Thick body (Table I). No body swellings. SEM showed oblique cuticular striations on lateral fields with elevated longitudinal bands in both sexes (Fig. 5B). Anterior part of intestine contained a yellow-green substance in many specimens of both sexes.

Female

External aspect of buccal capsule forming two small crests (Fig. 3F). Vulva at anterior level of esophagointestinal junction, and vagina large, longer than wide (Fig. 3A). Unpaired ovejector $700 \mu \mathrm{m}$ long, widening posteriorly before dividing into uteri; initial part of the two uteri folded into the same external wall (Fig. 3G, arrow); uteri become separate $1.4 \mathrm{~mm}$ from vagina. Tail slightly bent ventrally, attenuated posteriorly; extremity with two conical, lateroventral lappets, each as long as wide, and one larger dorsal lappet; no transverse crests (Fig. 3K). Phasmids anterior to lateroventral lappets (Fig. 3L).

Microfilaria (Fig. 3M-N): cephalic space $5 \mu \mathrm{m}$, nerve ring 28-40 (35) $\mu \mathrm{m}$ from anterior end: $26 \%$ of the body length, and excretory pore 53-58 (54) $\mu \mathrm{m}$ from anterior end: $40 \%$ of the body length. Body dorsoventrally flattened and straight in many specimens; posterior part without nuclei, 3-4 (4) $\mu \mathrm{m}$, and sharp but slightly blunted tail end (Fig. 3N). Sheath absent from uterine and skin specimens.

Male

Apex of testis posterior to the esophagointestinal junction (Fig. 4O, arrow). Area rugosa (Fig. 4S): 229 transverse bands, $5 \mu \mathrm{m}$ high and $18 \mu \mathrm{m}$ apart, extending from 2.7 to $1.1 \mathrm{~mm}$ from the tip of tail.

Three pairs of precloacal papillae arranged in two lines converging towards the cloacal aperture (Fig. 4U); unpaired precloacal papilla at the level of the most anterior pair (pair 2). Postcloacal pair 6, very large with swollen cuticle slightly posterior to pair 5 ; pair 7 very small, halfway along the tail. Pairs 8 and 9 near the caudal extremity. Caudal extremity (Fig. 4V) simple, conical, without defined cylinder; generally with no lateral lappets, or with small lappets if present. Spicules (Fig. 4X-Y-a): the right with dorsal heel and terminal cap; the left with handle and lamina longer than the handle; posterior part of the lamina with wide, slightly striated alae.

\section{Diagnosis}

C. crassa, which is a member of the group of Cercopithifilaria species from ruminants, is distinct from C. longa in many characters: body thickness, size of spicules, and more evolved arrangement of caudal papillae: reduced number of precloacal papillae in two converging lines and position of pair 8 of the papillae near pair 9. Microfilariae of C. crassa were shorter, thicker, and straighter than those of C. longa (Table I). The cephalic space of $C$. crassa microfilariae was smaller; the tail of the specimens was narrower than that of $C$. longa. The posterior third of C. longa microfilariae was attenuated. C. crassa adults and microfilariae are similarly distinct from $C$. bulboidea from the Japanese serow (Uni et al., 2001).

In the position of its terminal pairs of caudal papillae, $C$. crassa resembles the four other species from the Japanese serow - C. shoboi Uni, Suzuki \& Katsumi, 1998, C. multicauda Uni \& Bain, 2001, C. minuta Uni \& Bain, 2001, and C. tumidicervicata Uni \& Bain, 2001 - and 


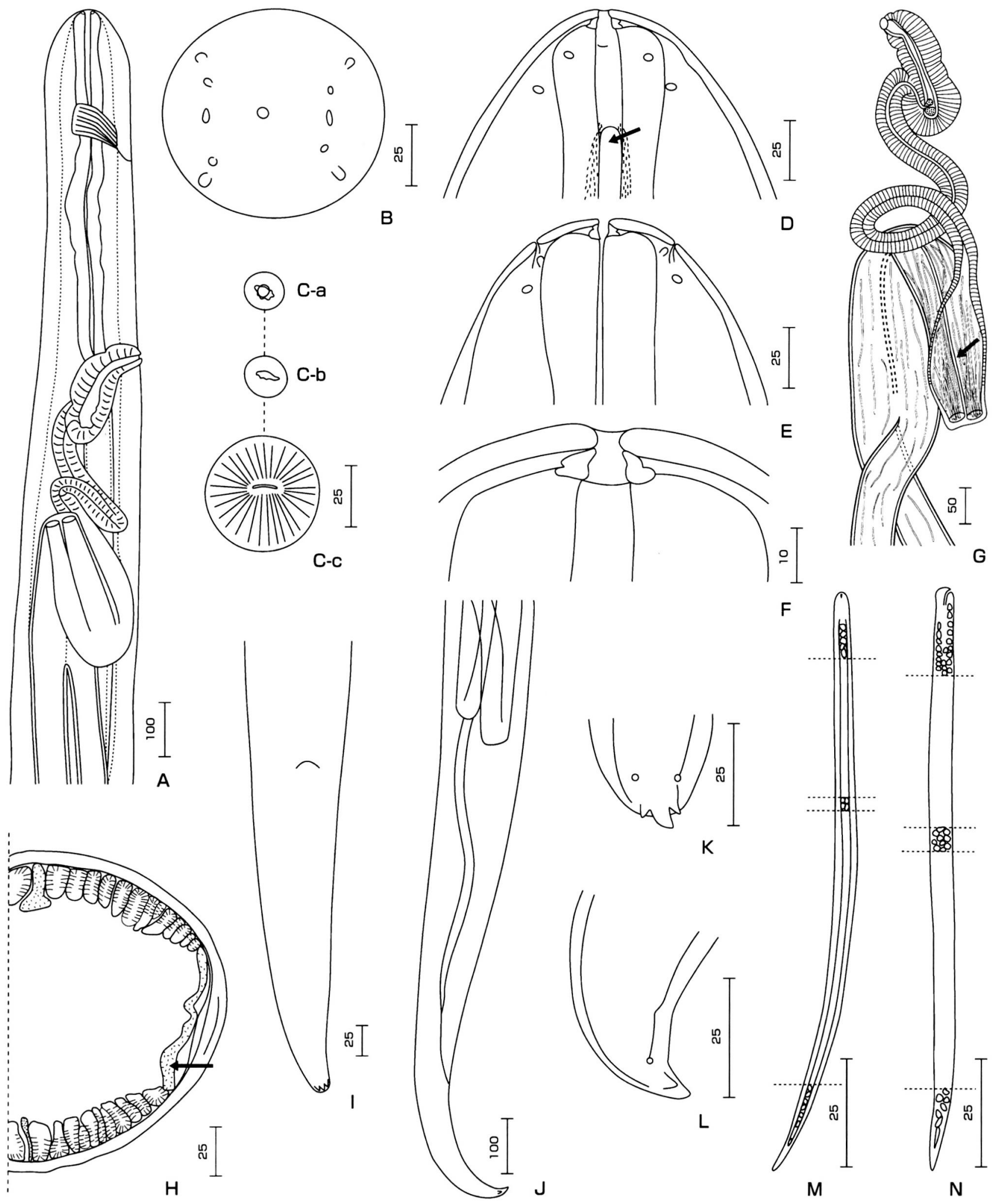

Fig. 3. - Cercopithifilaria crassa n. sp. A-L, females. A. Anterior part, lateral view. B. Anterior end, en face view. C-a. Mouth opening (small circle) and transverse section of the buccal capsule. C-b. Transverse section at base of buccal capsule. C-c. Transverse section at apex of esophagus. D. Head, with beginning of lateral chord (dots) and lateral cuticular thickening (arrow), lateral view. E. Head, median view. F. Buccal capsule, median view. G. Vagina, ovejector and division of uteri (arrow indicates the joined part). H. Transverse section of the midbody (arrow, lateral chord) I. Tail, ventral view. J. Posterior part, lateral view. K. Caudal extremity, ventral view. L. Caudal extremity, lateral view. M-N. Microfilariae. M. Entire body, left lateral view. N. Entire body, median view. Bars, micrometers. 

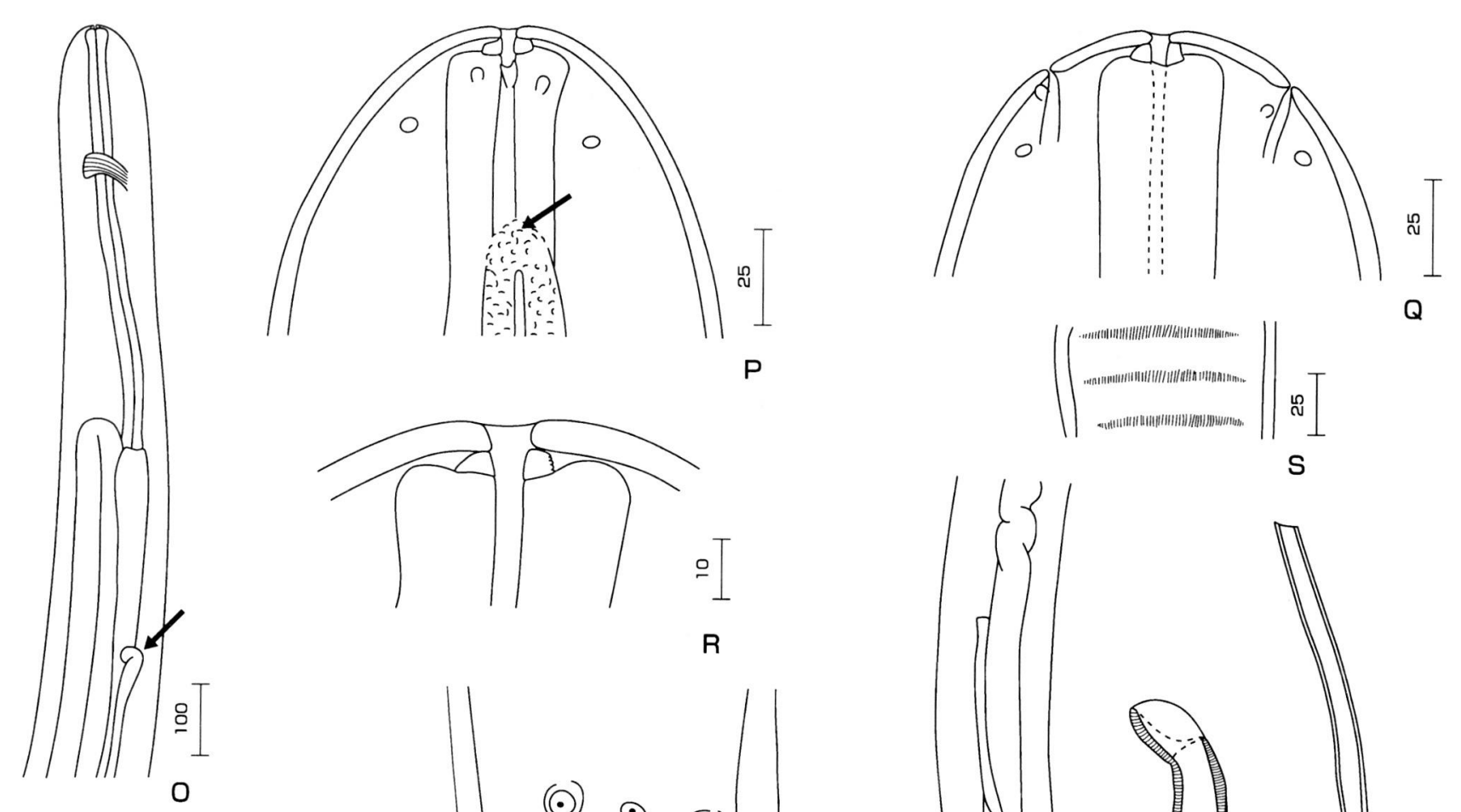

$\mathrm{s}$
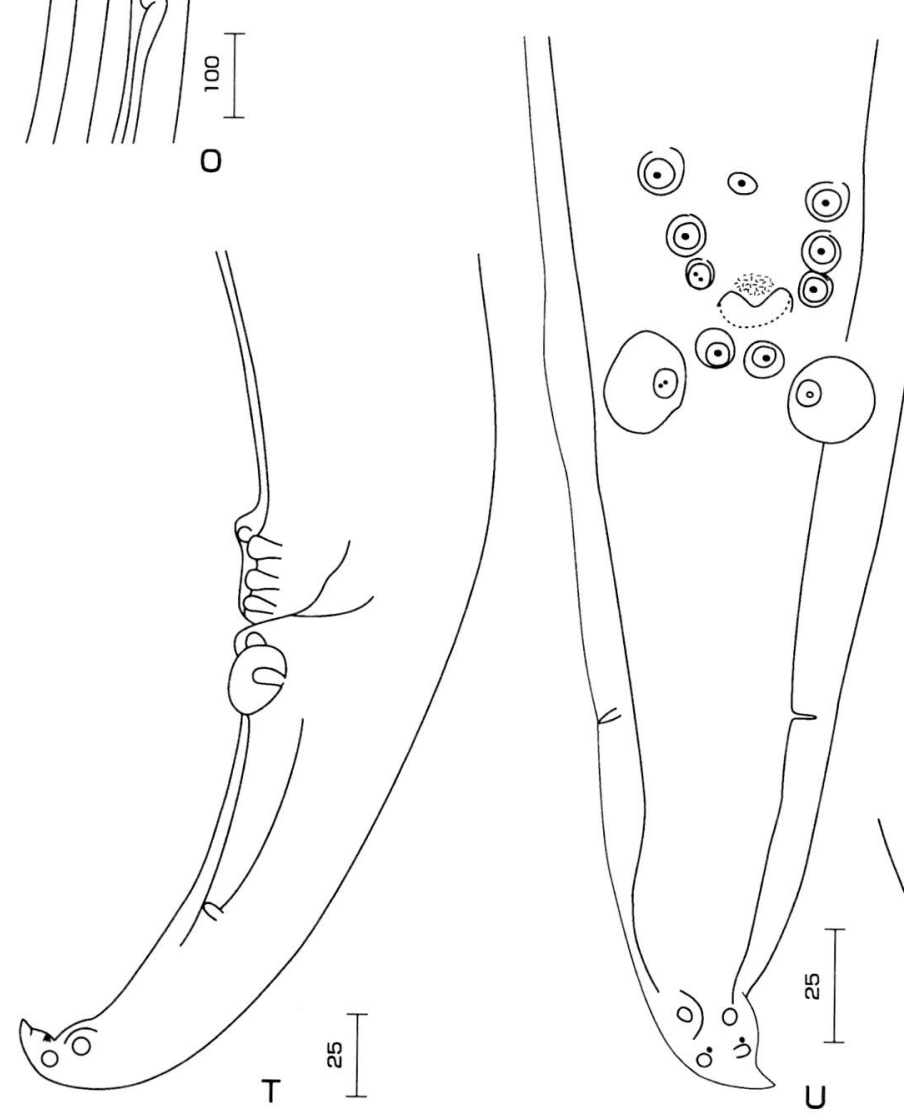

R

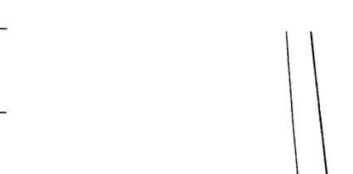



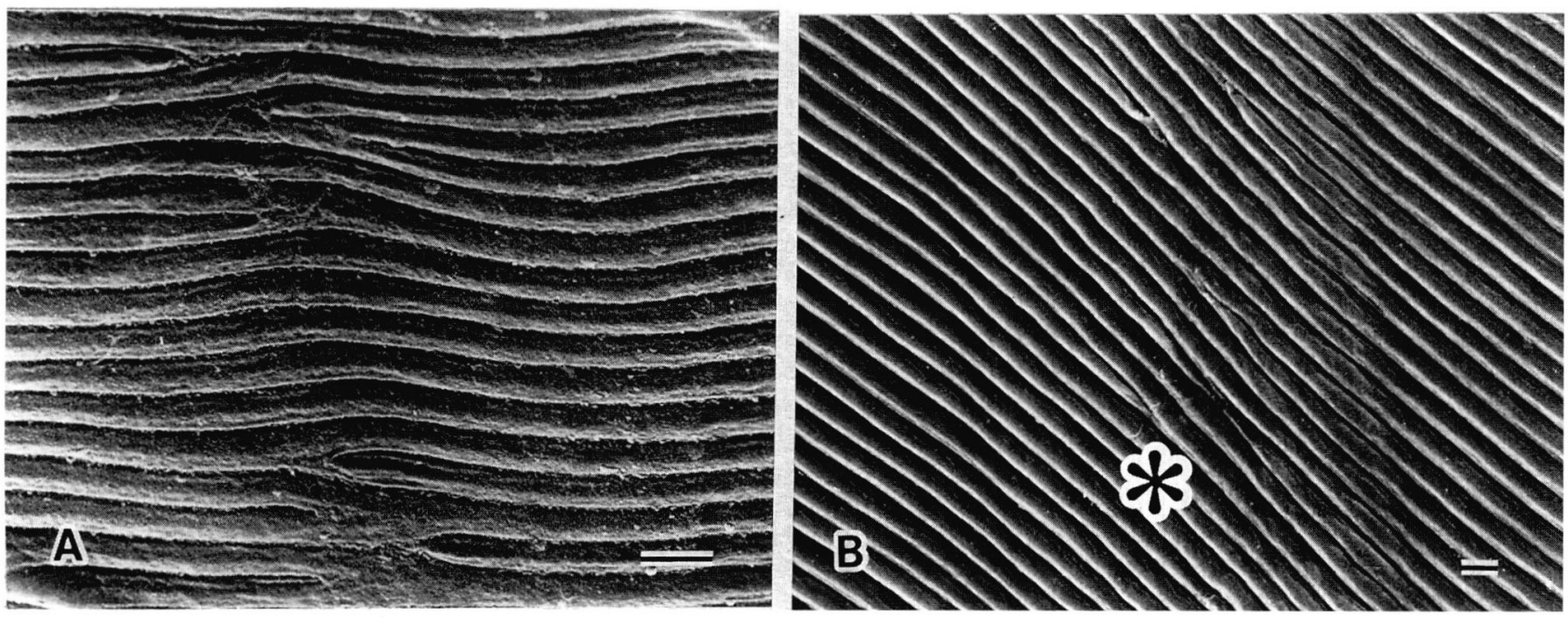

Fig. 5. - SEM of cuticular striations in the lateral field of the midbody of females. A, C. longa n. sp.; B, C. crassa n. sp. "Elevated area. Bars, $1 \mu \mathrm{m}$

the species from Capreolus capreolus, C. rugosicauda (Böhm \& Supperer, 1953).

The four cited species from Capricornis crispus are much thinner than C. crassa; the caudal extremities of those males have three distinct lappets, the precloacal papillae are arranged in two parallel lines that do not converge towards the cloacal aperture; in females, the two uteri are not initially joined together.

In addition, each species is distinguished from the new material by many characters, listed below:

- C. multicauda: very slight body swellings, cephalic papillae arranged in a rectangle stretched dorsoventrally, female caudal extremity complex, very elongated vagina, longer microfilaria shaped differently from that of C. crassa, pair 6 of the caudal papillae of normal size and pair 7 well developed, and area rugosa shorter (86 transverse bands compared with about 230 of C. crassa).

C. minuta: head with small subterminal bulb, no body swellings, cephalic papillae arranged as in C. multicauda, longer caudal lappets in the female, longer microfilaria not flattened dorsoventrally; in the male, shorter left spicule, pair 6 of the papillae more distant from pair 5, pair 7 well developed, and shorter area rugosa (120 bands).

- C. tumidicervicata: head with cervical bulb, ovejector five times longer, microfilaria three times larger with complex caudal cuticle, relative position of pairs 5 and 6 of the caudal papillae as in C. minuta, and only two pairs of precloacal papillae (numbers 3 and 4 ).

- C. shohoi: cuticular striae perpendicular to the axis of the body in the lateral fields, unlike the three previous species and $C$. crassa, in which they were oblique, postesophageal vulva, ovejector seven times longer, shorter microfilaria; in the male, nine pairs of caudal papillae all of similar sizes, papillae of pair 5 joined on the ventral line, and shorter left spicule.

The only species that is thick and has large spicules like C. crassa is C. rugosicauda, but this species is distinct in several characters: the presence of several peaks (crests) of different size on the female caudal extremity and the presence of a postvulvar swelling, the longer esophagus (850-880 and 770-780 $\mu \mathrm{m}$ in females and males, respectively), the longer microfilaria $(212-222 \mu \mathrm{m})$, the longer right spicule, and, after the redescription by Mészáros \& Sugár (1976), the shorter area rugosa (800-850 $\mu \mathrm{m}$ long compared with $1,600 \mu \mathrm{m}$, Table I), the male tail extremity with three points, and the male caudal papillae of similar size with the precloacal pairs in two parallel lines. C. crassa adults were in the skin, but $C$. rugosicauda adults were reported to be in the subcutaneous connective tissue of the host animals (Böhm \& Supperer, 1953).

\section{Prevalence, COINFECTION, AND DisTRIBUTION OF ADULT WORMS AND MICROFILARIAE \\ OF C. LONGA AND C. CRASSA IN SIKA DEER}

The adult filariae reached high densities in the sika, so precise information on their locations in the host could be obtained. Adult worms of Cercopithifilaria species were found in $12(71 \%)$ deer of the 17 examined: C. longa was present in all infected animals, but C. crassa was found in only six (35\%) animals and always in association with the first species.

Adult worms of C. longa were found in the subcutaneous tissues, mainly of the limbs and abdomen, their microfilariae occurring in the skin of thoracic limbs (six deer), pelvic limbs (five deer), trunk, and neck; none was found in ear skin. Adult worms of $C$. crassa were 
found embedded in the skin of the anterior back and a few in the trunk, with their microfilariae in the back (five deer), ears (three deer), neck, abdomen, and tail. These specific locations were confirmed in the deer (S15) with the heaviest double infection: 102 adult worms of C. longa and 118 of C. crassa were recovered from the subcutaneous tissues and the skin, respectively. With C. longa, $72 \%$ of the parasites were found in the limbs (maximum density, eight worms per $100 \mathrm{~cm}^{2}$, on the surface of the $m$. triceps brachii and $m$. triceps surae) and the remainder were found in the abdomen and upper regions of the limbs. With C. crassa, $57 \%$ of the worms were found in the skin of the anterior back (maximum density, eight worms per $100 \mathrm{~cm}^{2}$ ), with none in the skin of the limbs.

\section{CONCLUSIONS}

the host range of Cercopithifilaria species comprises many groups of zoologically unrelated 1 mammals. Our findings about the new species confirm that, as previously suggested (Uni et al., 2001), those species parasitic in the ruminants Bovidae and Cervidae are morphologically the most primitive. They constitute the basal stock from which are derived diverse other lineages, by capture (sensu Chabaud, 1982) via their tick vectors (Chabaud \& Bain, 1994).

We now know of 12 species parasitic in ruminants, of which seven occur in Japan. A certain degree of evolution has taken place in this group. The four species parasitic in African Bovidae (Bovinae and Cephalophinae) are particularly primitive. The African species are closely related to two species from Japan: C. longa and C. bulboidea, parasites of a modern cervid (the elaphus group, Geist, 1998) and a caprine bovid, from the most recent branch of the family (Hassanin et al., 1998), respectively.

We do not know of any primitive species in continental Eurasia. The single species of Cercopithifilaria known in this region, a parasite of the cervid Capreolus capreolus, is a specialized form. We may thus suppose the existence of primitive forms, not yet described or already extinct, in continental Eurasia,

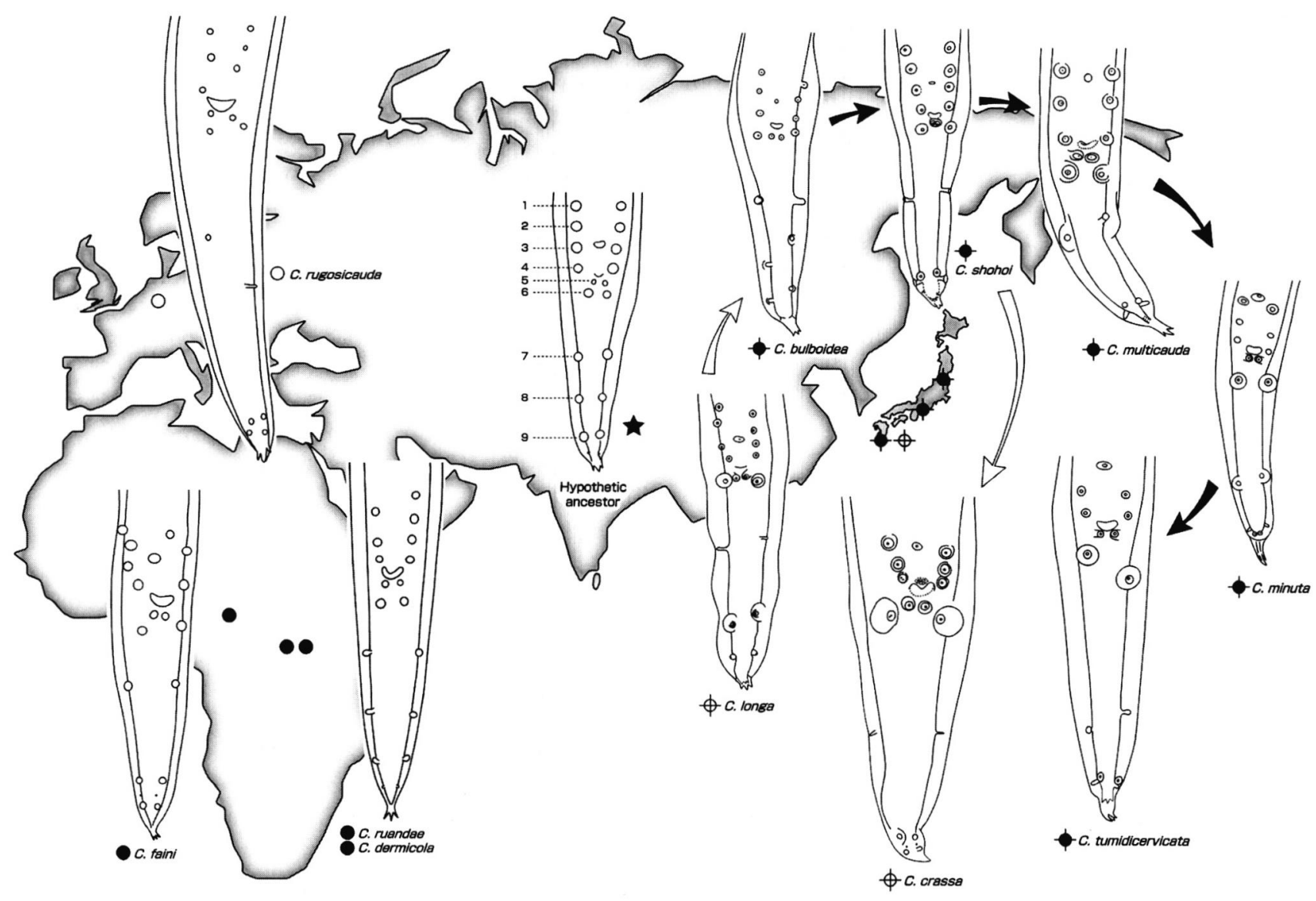

Fig. 6. - Hypothesis about the evolution of Cercopithifilaria species from ruminants. Caudal parts of males are superimposed on a world map. Bold arrows: successive speciations in Capricornus crispus. Open arrows: two speciations by captures, the first (shorter arrow) from sika to serow, and the second in the opposite direction. Star, hypothetic ancestor. Bold circles, bovids; open circles, cervids. Symbols for organisms found in Japan are marked with a plus symbol. 
which gave rise to the primitive species in Africa and Japan. These Eurasian ancestral forms must have evolved, like their hosts (Thomas, 1992), since the Middle Miocene.

The origin of C. crassa remains debatable because it morphologically resembles $C$. rugosicauda and the highly evolved species from the Japanese serow. We think it probable that it arose locally, either by capture of a species from the serow or by evolution of C. longa, because it has a morphological apomorphic character peculiar to Japan (the hypertrophy of some pairs of caudal papillae).

The exceptional diversification observed among the Cercopithifilaria species of the two wild ruminants in Japan may have arisen, as we hypothesize (Fig. 6), from successive speciations of a basal stock of the C. longa type. This basal species would have arrived with its cervid host over southern bridges established with the Eurasiatic continent during the late PliocenePleistocene (Soma et al., 1987; Kawamura, 1998). The arrival of the serow seems to be dated to the Middle Pleistocene, 500,000-250,000 years ago (Dobson \& Kawamura, 1998), when capture of Cercopithifilaria species from cervids could have occurred.

The fragmented and unstable geography of Japan later favored the temporary isolation of populations of the hosts and their filariae. As with other parasites (Chabaud \& Durette-Desset, 1978), such circumstances allowed the emergence of new species and the persistence of some of them, despite strong competition between congeneric species. In the case of Cercopithifilaria species from the Japanese sika and serow, the morphologically more evolved species were in the dermis, and the morphologically primitive species inhabited the subcutaneous tissue.

\section{ACKNOWLEDGEMENTS}

W Te thank Dr J. Baker and Ms C. Latta for reading the manuscript. This study was supported in part by grants 10306020 and 12877043 from the Ministry of Education, Science, Sports, and Culture, Japan.

\section{REFERENCES}

Bain O., Baker M. \& Chabaud A.G. Nouvelles données sur la lignée Dipetalonema (Filarioidea, Nematoda). Annales de Parasitologie Humaine et Comparée, 1982, 57, 593-620.

Bain O., Chabaud A.G. \& Georges A.J. Nouvelle filaire du genre Cercopithifilaria, parasite d'un carnivore africain. Parassitologia, 1987, 29, 63-69.

BöHм L.K. \& SuPPERER R. Beobachtungen über eine neue Filarie (Nematoda), Wehrdikmansia rugosicauda Böhm \&
Supperer 1953, aus dem subkutanen Bindegewebe des Rehes. Sitzungsberichte, Abt. 1, Biologie, Mineralogie, Erdkunde und verwandte Wissenschaften, Österreichische Akademie der Wissenschaften, Mathematisch-Naturwissenschaftliche Klasse, 1953, 162, 95-103.

Chabaud A.G. Spectre d'hôtes et évolution des nématodes parasites de vertébrés. In: $2^{\text {ème }}$ Symposium sur la Spécificité parasitaire des Parasites de Vertébrés, 1981, Mémoires de Muséum National d'Histoire Naturelle, Série A. Zool., 1982, 123, 73-76.

Chabaud A.G. \& Bain O. The evolutionary expansion of the Spirurida. International Journal for Parasitology, 1994, 24, 1179-1201.

Chabaud A.G. \& Durette-Desset M.C. Parasitisme par plusieurs espèces congénériques. Bulletin de la Société Zoologique de France, 1978, 103, 459-464.

Chabaud A.G., Landau I. \& Petit G. Deux filaires de Céphalophes au Gabon. Annales de Parasitologie Humaine et Comparée, 1978, 53, 285-290.

Chabaud A.G. \& Petter A.J. Remarques sur l'évolution des papilles cloacales chez les nématodes phasmidiens parasites de vertébrés. Parassitologia, 1961, 3, 51-70.

Demiaszkiewicz A.W., Dróżdż J. \& Lachowicz J. Occurrence of microfilariae from subfamily Onchocercinae in red and roe deer in Bieszczady Mountains. Helminthologia, 2001, 38, 111-113.

Dobson M. \& Kawamura Y. Origin of the Japanese land mammal fauna: allocation of extant species to historicallybased categories. Quaternary Research, 1998, 37, 385-395.

EBERHARD M.L. Dipetalonema (Cercopithifilaria) kenyensis subgen. et sp. n. (Nematoda: Filarioidea) from African baboons, Papio anubis. Journal of Parasitology, 1980, 66, 551-554.

FAIN A. Parasitisme intradermique par les nématodes chez les bovins au Rwanda. Description de deux nouvelles espèces. Annales de la Société Belge de Médecine Tropicale, 1977, 57, 113-120

Fain A. \& Herin V. Filarioses des bovidés au Ruanda-Urundi. III. - Étude parasitologique. Annales de la Société Belge de Médecine Tropicale, 1955, 35, 535-554.

Geist V. Deer of the world: their evolution, behavior, and ecology. Stackpole Books, Mechanicsburg, PA, USA, 1998, $421 \mathrm{pp}$.

GrubB P. Family Cervidae. In: Mammal species of the world: a taxonomic and geographic reference. Wilson D.E. \& Reeder D.M. (eds), Smithsonian Institution Press, Washington D.C., 1993, 384-392.

Hassanin A., Pasquet E. \& Vigne J.D. Molecular systematics of the subfamily Caprinae (Artiodactyla, Bovidae) as determined from cytochrome $b$ sequences. Journal of Mammalian Evolution, 1998, 5, 217-236.

KAWAMURA Y. Immigration of mammals into the Japanese Islands during the Quaternary. Quaternary Research, 1998, 37, 251-257.

MÉSzÁros F. \& SugÁr L. Dipetalonema rugosicauda (Böhm and Supperer, 1953) nov. comb.: occurrence in roe deer in Hungary. Parasitologia Hungarica, 1976, 9, 67-71. 
Soma H., Kada H. \& Matayoshi K. Evolutionary pathways of karyotypes of the tribe Rupicaprini. In: The biology and management of Capricornis and related mountain antelopes. Soma H. (ed), Croom Helm, London, 1987, 62-71.

Thomas H. Crise climatique et événements géodynamiques : leur rôle dans l'évolution des primates anthropoïdes. Bibliothèque d'Orientation Menta, Paris, 1992, 92 pp.

UNI S. Filarial parasites from the black bear of Japan. Annales de Parasitologie Humaine et Comparée, 1983, 58, 71-84.

Uni S., Suzuki Y. \& Katsumi A. Cercopithifilaria shohoi n. sp. (Nematoda: Filarioidea) from the relict Bovidae, Capricornis crispus, in Japan. Parasite, 1998, 5, 119-126.

Uni S., SuZuki Y., Baba M., Mitani N., Takaoka H., Katsumi A. \& Bain O. Coexistence of five Cercopithifilaria species in the Japanese rupicaprine bovid, Capricornis crispus. Parasite, 2001, 8, 197-213.

Reçu le 26 mars 2002 Accepté le 24 juillet 2002 